\title{
Expression of Notch I receptor associated with tumor aggressiveness in papillary thyroid carcinoma
}

\author{
This article was published in the following Dove Press journal: \\ OncoTargets and Therapy \\ 15 March 2016 \\ Number of times this article has been viewed
}

\author{
Hongliang $\mathrm{Fu}^{\prime}$ \\ Chao Ma' \\ Wenbin Guan ${ }^{2}$ \\ Weiwei Cheng' \\ Fang Feng' \\ Hui Wang' \\ 'Department of Nuclear Medicine, \\ ${ }^{2}$ Department of Pathology, Xin Hua \\ Hospital, Shanghai Jiao Tong University, \\ School of Medicine, Shanghai, People's \\ Republic of China
}

Aim: The aim of this study was to assess if the expression of Notch 1 receptor is associated with tumor aggressiveness in papillary thyroid carcinomas (PTCs).

Patients and methods: By searching the electronic medical record system of Xin Hua Hospital, all cases of PTC patients who underwent thyroidectomy in the hospital between 2013 and 2014 were retrieved. Then, the cases of patients who had a history of any other malignancy or whose thyroid tumor specimen was not available for assay were rejected. Finally, 68 cases of PTC patients were obtained. Formalin-fixed paraffin-embedded tissue blocks of these patients were studied by immunohistochemistry to learn the expression of Notch 1 receptor. Meanwhile, the clinical data of these patients including sex, age, size of the tumor, presence of node metastasis or distant metastasis, and presence of capsule invasion and tumor multicentricity were collected. Pearson's chi-square test or Fisher's exact test was used for measuring statistical differences in categorical variables. All the statistical tests were two-sided. A $P$-value $<0.05$ was considered to be statistically significant.

Results: A total of 19 male and 49 female PTC patients with a mean age of $44.8 \pm 13.6$ years (range 18-78 years) were studied. Notch 1 receptor expression was found in 15/68 (22\%) samples of PTC. The expression of Notch 1 receptor was significantly associated with tumor size $(P=0.021)$, distant metastasis $(P=0.008)$, capsule invasion $(P=0.001)$, tumor multicentricity $(P=0.018)$, and age $(P=0.033)$. However, the expression of Notch 1 receptor was not significantly correlated with node metastasis $(P=0.096)$ and sex $(P=0.901)$.

Conclusion: The expression of Notch 1 receptor is associated with tumor aggressiveness in PTC, and may be used as a molecular marker of tumor invasiveness in PTC. PTC patients who show positive expression of Notch 1 receptor may benefit from radioiodine remnant ablation. Keywords: papillary thyroid carcinoma, Notch 1 receptor, tumor aggressiveness, radioiodine remnant ablation

\section{Introduction}

Receptors and ligands of the Notch family are widely expressed in normal, reactive, and neoplastic tissues as important regulators of cellular growth and differentiation. ${ }^{1-3}$ The role of the Notch signaling pathway in a variety of malignant tumors has been investigated. In human cancer cells, Notch plays a dual role as either an oncogene or a tumor suppressor. On one hand, the activation of the Notch signaling pathway inhibits apoptosis or chemoresistance of cancer cells in ovarian, colorectal, or pancreatic cancer, suggesting an oncogenic role. ${ }^{4-7}$ On the other hand, the activation of the Notch signaling pathway has been shown to inhibit the growth of prostate cancer, small-cell lung cancer, basal cell cancer, and pancreatic carcinoid, suggesting a role of cancer suppressor. ${ }^{8-11}$

Studies on the Notch signaling pathway or Notch receptor in thyroid cancer are mainly focused on poorly differentiated thyroid cancer (DTC) or anaplastic
Correspondence: Hui Wang

Department of Nuclear Medicine,

Xin Hua Hospital, Shanghai Jiao Tong

University, School of Medicine, 1665

Kongjiang Road, Shanghai 200092,

People's Republic of China

Tel +86 2I 25076980

Fax +86 21 25076996

Email wanghuishanghai@hotmail.com
OncoTargets and Therapy 2016:9 1519-1523

(c) (i) ( $2016 \mathrm{Fu}$ et al. This work is published and licensed by Dove Medical Press Limited. The full terms of this license are available at https://www.dovepress.com/terms.php cc. ${ }_{\mathrm{BY}} \mathrm{NC}$ and incorporate the Creative Commons Attribution - Non Commercial (unported, v3.0) License (http://creativecommons.org/licenses/by-nd/3.0/). By accessing the work you hereby accept the Terms. Non-commercial uses of the work are permitted without any further permission from Dove Medical Press Limited, provided the work is properly attributed. For permission for commercial use of this work, please see paragraphs 4.2 and 5 of our Terms (https://www.dovepress.com/terms.php).

1519
Dovepress

http://dx.doi.org/1 0.2147/OTT.S98239 
thyroid cancer. The role of the Notch receptor or signaling pathway has not yet been fully elucidated in DTC. The role of the Notch signaling pathway in thyroid cancers may differ apparently according to their histological type. The aim of this study was to examine whether there was some association between Notch 1 receptor expression and tumor aggressiveness in papillary thyroid carcinoma (PTC) by immunohistochemistry (IHC).

\section{Patients and methods}

\section{Patients}

This was a retrospective study, and the patients in this study were consecutively enrolled. Patients provided written informed consent to participate. The study was approved by the Institutional Review Board of Xin Hua Hospital, Shanghai Jiao Tong University, School of Medicine (Shanghai, People's Republic of China) and in accordance with the precepts established by the Helsinki declaration. All the cases of PTC patients who underwent thyroidectomy in our hospital between 2013 and 2014 were retrieved by searching the electronic medical record system. After rejecting the cases of patients who had a history of any other malignancy or whose thyroid tumor specimen was not available for IHC assay, 68 cases of PTC were finally obtained in this study. Information on demographic characteristics and pathological variables were abstracted. The demographic and clinical variables included age, sex, tumor size, status of lymph node metastasis or distant metastasis, and presentation of capsule invasion and tumor multicentricity.

\section{IHC assay of Notch I receptor}

The specimens of these 68 PTC patients were confirmed histologically by a pathologist who specialized in thyroid pathology. IHC staining was performed on sections ( $4 \mu \mathrm{m}$ thick) and deparaffinized through graded alcohols. Endogenous peroxidase activity was blocked with $3 \%$ hydrogen peroxide for 10 minutes. For antigen retrieval, tissue slides were heated in $0.01 \mathrm{M}$ sodium citrate solution ( $\mathrm{pH}$ 6.0) in a pressure cooker treated for 30 minutes. Nonspecific binding was blocked with $10 \%$ normal rabbit serum for 10 minutes. The tissue slides were incubated with anti-Notch-1 primary antibody (Notch 1 (D1E11) XP ${ }^{\circledR}$ Rabbit mAb, 1:100 dilution; Cell Signaling Technology, MA, USA) for 6 hours at room temperature. The slides were then incubated with biotinylated rabbit anti-mouse immunoglobulin for 10 minutes and reacted with horse radish peroxidase for 10 minutes. For a negative control, the primary antibody was omitted in the staining procedure.

\section{Interpretation of immunohistochemical staining}

IHC staining was assessed in five power fields at $200 \times$ magnification. Immunoreactivity was evaluated semiquantitatively based on staining proportion and intensity. The stained tissues were scored by a pathologist who was blinded to patients' clinical data. The intensity of the immunoreaction for Notch 1 was measured using a descriptive scale as follows: negative staining, weakly positive staining, and positive staining (Figure 1).

\section{Statistical analysis}

Pearson's chi-square test or Fisher's exact test was used for measuring statistical differences in categorical variables. All the statistical tests were two-sided. A $P$-value $<0.05$ was considered to be statistically significant. All the calculations were carried out using the SPSS version 13.0 statistical software package (SPSS Inc., Chicago, IL, USA).

\section{Results}

\section{Patients and basic clinicopathological characteristics}

Of the 68 patients included in the study, 19 were males and 49 were females, whose mean age at surgery was $44.8 \pm 13.6$ years (range 18-78 years). Patient and tumor characteristics in the study are shown in Table 1.

\section{IHC of Notch I receptor}

As shown in Table 2, Notch 1 receptor expression was found in 15 of 68 cases $(22.1 \%)$. The expression of the Notch 1 receptor was significantly associated with poor prognostic markers including larger tumor size $(P=0.021)$, distant metastasis $(P=0.008)$, capsule invasion $(P=0.001)$, tumor multicentricity $(P=0.018)$, and age $(P=0.033)$. However, there was no significant association with node metastasis $(P=0.096)$ and $\operatorname{sex}(P=0.901)$.

\section{Discussion}

Radioiodine remnant ablation (RRA) is believed to be beneficial in decreasing the rate of recurrence in the high-risk group of DTC. ${ }^{12,13}$ However, not all the PTC patients need the RRA according to the guidelines. ${ }^{14,15}$ In order to determine whether a PTC patient could benefit from RRA, the current evaluation system, mainly consisting of clinicopathological characteristics such as histological type, TNM staging, and age and sex of patients, is used to identify whether a patient is in a high-risk group. ${ }^{14,15}$ 


\section{A}

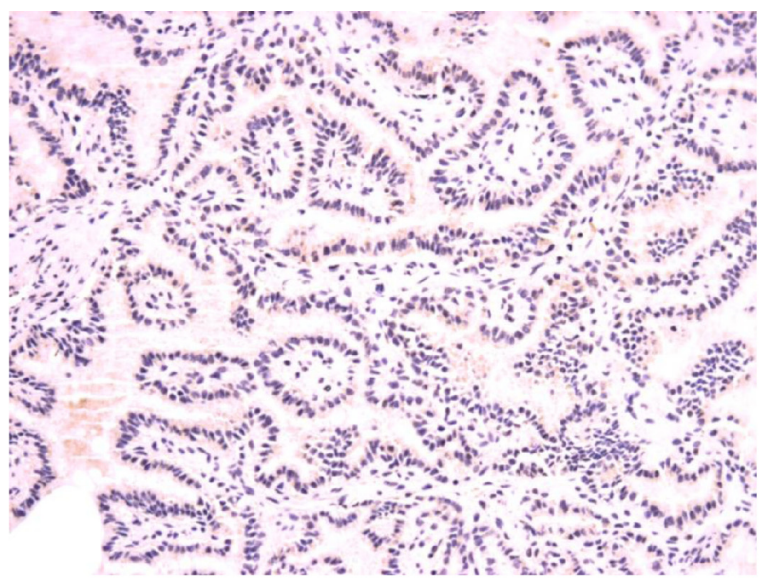

B

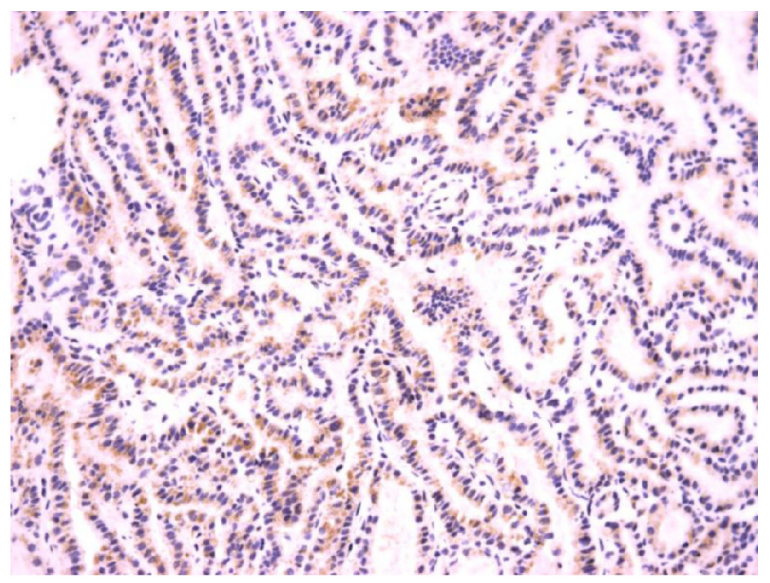

\section{C}

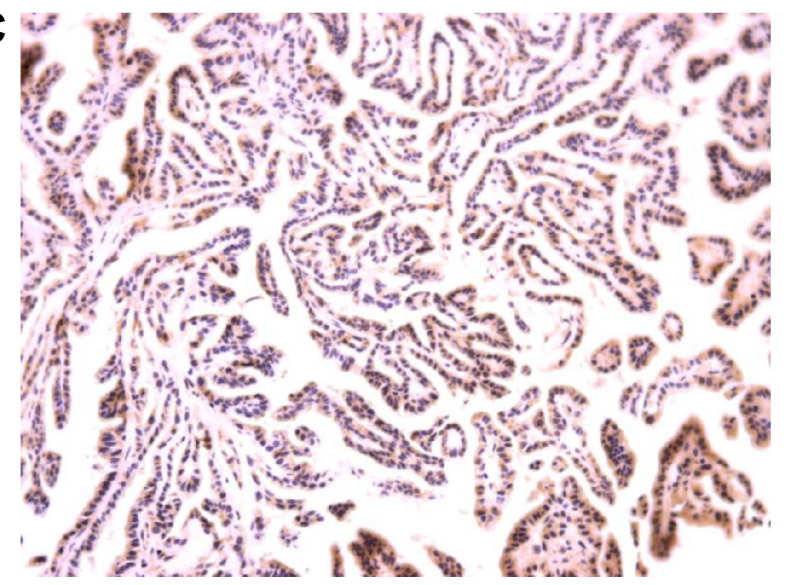

Figure I Representative Notch I receptor immunohistochemistry (200x) of three papillary thyroid carcinomas.

Notes: (A) Notch I-negative group, (B) Notch I-weakly positive group, and (C) Notch I-positive group. Intratumoral erythrocytes served as positive controls.

Table I Basic clinicopathological features of tumors

\begin{tabular}{lll}
\hline Features & \multicolumn{2}{l}{ Frequencies } \\
\cline { 2 - 3 } & Number & Percentage \\
\hline Sex & 19 & 27.9 \\
Male & 49 & 72.1 \\
$\quad$ Female & & \\
Age (years) & 29 & 42.6 \\
$\quad \leq 45$ & 39 & 57.4 \\
$>45$ & & \\
Tumor size (cm) & 58 & 85.3 \\
$\quad \leq 2$ & 10 & 14.7 \\
$>2$ & & \\
Node metastasis & 31 & 45.6 \\
$\quad$ Absent & 37 & 54.4 \\
Present & & \\
Distant metastasis & 64 & 94.1 \\
Absent & 4 & 5.9 \\
Present & & \\
Capsular invasion & 59 & 13.2 \\
Absent & 9 & 72.1 \\
Present & & 27.9 \\
Multicentricity & 49 & \\
Absent & 19 & \\
Present & & \\
\hline
\end{tabular}

Much data have shown that some molecular markers or signaling pathways may have close relationship with tumor genesis or development. ${ }^{16}$ The Notch receptor has been shown to be such a molecular marker. ${ }^{17}$ The Notch signaling was first linked to tumorigenesis in T-cell acute lymphoblastic leukemia. ${ }^{18}$ From then on, aberrant Notch signaling has been investigated in various tumors. The Notch pathway is known to play the role of either an oncogene or a tumor suppressor depending on the level of signaling activity and type of cancer cells. ${ }^{4-11}$ However, limited studies on the Notch signaling pathway or receptor in DTC have been conducted, and the role of Notch receptor expression in DTC is not clear. In this study, we investigated the correlation between the expression of Notch 1 receptor and tumor aggressiveness in PTCs.

As we know, large tumor size, lymph node metastasis, distant metastasis, capsule invasion, and multicentricity are high-risk clinicopathological characteristics in PTC. Postsurgical PTC patients with these high-risk variables are advised to accept RRA according to the guidelines because 
Table 2 Observations of expression of Notch I receptor by IHC

\begin{tabular}{|c|c|c|c|}
\hline \multirow[t]{3}{*}{ Characteristics } & \multicolumn{2}{|c|}{ Notch I receptor } & \multirow[t]{3}{*}{$P$-value } \\
\hline & Negative & Positive & \\
\hline & $\mathrm{N}=53(\%)$ & $\mathbf{N}=\mathbf{I} 5(\%)$ & \\
\hline \multicolumn{4}{|l|}{ Sex } \\
\hline Male & I5 (78.9) & $4(2 I . I)$ & 0.901 \\
\hline Female & $38(78.4)$ & II (2I.6) & \\
\hline \multicolumn{4}{|l|}{ Age (years) } \\
\hline$<45$ & $27(90.0)$ & $3(10.0)$ & 0.033 \\
\hline$\geq 45$ & $26(68.4)$ & $12(31.6)$ & \\
\hline \multicolumn{4}{|l|}{ Tumor size $(\mathrm{cm})$} \\
\hline$\leq 2$ & $48(82.8)$ & $10(17.2)$ & 0.021 \\
\hline$>2$ & $5(50.0)$ & $5(50.0)$ & \\
\hline \multicolumn{4}{|l|}{ Node metastasis } \\
\hline No & $27(87.1)$ & $4(12.9)$ & 0.096 \\
\hline Yes & $26(70.3)$ & II (29.7) & \\
\hline \multicolumn{4}{|l|}{ Distant metastasis } \\
\hline No & $52(81.3)$ & $12(18.7)$ & 0.008 \\
\hline Yes & I (25.0) & $3(75.0)$ & \\
\hline \multicolumn{4}{|l|}{ Capsule invasion } \\
\hline Yes & $3 / 33.3$ & $6(66.7)$ & 0.001 \\
\hline No & $50(84.7)$ & $9(15.3)$ & \\
\hline \multicolumn{4}{|l|}{ Multicentricity } \\
\hline Yes & II (57.9) & $8(42.1)$ & 0.018 \\
\hline No & $42(85.7)$ & $7(14.3)$ & \\
\hline
\end{tabular}

Abbreviation: IHC, immunohistochemistry.

these patients are prone to recurrence or metastasis. ${ }^{14-16}$ The purpose of our study was to find if there is some association between the expression of Notch 1 receptor and these high-risk clinicopathological characteristics. The IHC result of the study showed that the expression of Notch 1 receptor was closely related to larger tumor size $(>2 \mathrm{~cm})$, distant metastasis, capsule invasion, and multifocal tumor. This implies that PTC patients with positive expression of Notch 1 receptor may tend to have more tumor invasiveness and could benefit from RRA. Park et al also studied the role of Notch receptor expression in PTC patients in an IHC study and found similar results in their study. ${ }^{19}$

Interestingly, the expression of Notch 1 receptor was not so closely related to node metastasis in our results. This result is contrary to the finding of Park et al. ${ }^{19}$ They found that Notch 1 receptor expression was closely related to node metastasis, and believed that Notch 1 receptor expression may be a predictive marker of node metastasis. In fact, there is often a conflict over the prognostic impact of lymph node involvement in DTC, especially regarding survival. Though several studies have identified an association between lymph node metastases and increased risk of cancer-related death, ${ }^{20,21}$ other studies failed to demonstrate an effect on mortality rates. ${ }^{22,23}$ Our data show that Notch expression is not necessarily associated with node metastasis. But, our result may imply that the expression of Notch 1 receptor might not pose any effect on node metastasis in PTC patients.

In our study, we also analyzed the relationship between the expression of Notch 1 receptor and age and sex of the patients. The results showed that only age had close association with the expression of Notch 1 receptor. As we know, the TNM system is the most widely adopted system for PTC. The TNM system for DTC considers a patient's age at diagnosis as an important variable. Although patients under 45 years of age have far more frequent lymph node involvement, they also have a far better outcome than older patients. With regard to sex of patients, there is no significant difference in mortality between males and females, though the incidence of PTC in females is higher than males according to the SEER investigation. ${ }^{24}$

A limitation of our study is its small sample size, though we think some features are already statistically different between samples with negative and positive Notch 1 receptor expression with the available sample size. This is mainly due to the lack of surgical specimens and surgical specimen size restrictions in this study. The other limitation of our study is that we have not conducted further experiments to investigate the possible mechanism involved in the association between Notch expression and tumor aggressiveness in PTC. Future experiments may be needed to supplement and improve the current results.

Finally, we draw the following conclusion that the expression of Notch 1 receptor is closely associated with tumor aggressiveness in PTC patients. The expression of Notch 1 could be used as an important indicator of tumor invasiveness in PTC.

\section{Acknowledgment}

This work was supported by the National Natural Science Fund (grant 51233007, 81270016, and 81401439), Shanghai Natural Science Fund (grant 14DZ1940603), Shanghai Pujiang Program (grant 13PJD022), and Shanghai Health Bureau Fund (grant 20124016).

\section{Disclosure}

The authors report no conflicts of interest in this work.

\section{References}

1. Rehman AO, Wang CY. Notch signaling in the regulation of tumor angiogenesis. Trends Cell Biol. 2006;16:293-300.

2. Kopan R, Ilagan MX. The canonical Notch signaling pathway: unfolding the activation mechanism. Cell. 2009;137:216-233.

3. Dumortier A, Durham AD, Di Piazza M, et al. Atopic dermatitis-like disease and associated lethal myeloproliferative disorder arise from loss of Notch signaling in the murine skin. PLoS One. 2010;5(2):e9258. 
4. Mann CD, Bastianpillai C, Neal CP, et al. Notch3 and hey-1 as prognostic biomarkers in pancreatic adenocarcinoma. PLoS One. 2012; 7(12):e51119.

5. Rose SL, Kunnimalaiyaan M, Drenzek J, Seiler N. Notch 1 signaling is active in ovarian cancer. Gynecol Oncol. 2010;117(1):130-133.

6. Sun W. Angiogenesis in metastatic colorectal cancer and the benefits of targeted therapy. J Hematol Oncol. 2012;5:63.

7. Kang M, Jiang B, Xu B, et al. Delta like ligand 4 induces impaired chemo-drug delivery and enhanced chemoresistance in pancreatic cancer. Cancer Lett. 2013;330:11-21.

8. Shou J, Ross S, Koeppen H, de Sauvage FJ, Gao WQ. Dynamic of Notch expression during murine prostate development and tumorigenesis. Cancer Res. 2001;61:7291-7297.

9. Restivo G, Nguyen BC, Dziunycz P, et al. IRF6 is a mediator of Notch pro-differentiation and tumor suppressive function in keratinocytes. EMBO J. 2011;30(22):4571-4585.

10. Borges M, Linnoila RI, van de Velde HJ, et al. An achaete-scute homologue essential for neuroendocrine differentiation in the lung. Nature. 1997;386:852-855.

11. Sriuranpong V, Borges MW, Ravi RK, et al. Notch signaling induces cell cycle arrest in small cell lung cancer cells. Cancer Res. 2001;61: 3200-3205.

12. Sawka AM, Thephamongkhol K, Brouwers M, Thabane L, Browman G, Gerstein HC. Clinical review 170: a systematic review and metaanalysis of the effectiveness of radioactive iodine remnant ablation for well-differentiated thyroid cancer. J Clin Endocrinol Metab. 2004; 89(8):3668-3676.

13. Mazzaferri EL, Jhiang SM. Long-term impact of initial surgical and medical therapy on papillary and follicular thyroid cancer. Am J Med. 1994; 97(5):418-428.

14. Cooper DS, Doherty GM, Haugen BR, et al. Revised American Thyroid Association management guidelines for patients with thyroid nodules and differentiated thyroid cancer. Thyroid. 2009;19(11):1167-1214.
15. Luster M, Clarke SE, Dietlein M, et al. Guidelines for radioiodine therapy of differentiated thyroid cancer. Eur J Nucl Med Mol Imaging. 2008;35(10):1941-1959.

16. Handkiewicz-Junak D, Czarniecka A, Jarzab B. Molecular prognostic markers in papillary and follicular thyroid cancer: current status and future directions. Mol Cell Endocrinol. 2010;322(1-2):8-28.

17. Allenspach EJ, Maillard I, Aster JC, Pear WS. Notch signaling in cancer. Cancer Biol Ther. 2002;1:466-476.

18. Ellisen LW, Bird J, West DC, et al. TAN-1, the human homolog of the Drosophila notch gene, is broken by chromosomal translocations in T lymphoblastic neoplasms. Cell. 199;166:649-661.

19. Park HS, Jung CK, Lee SH, et al. Notch1 receptor as a marker of lymph node metastases in papillary thyroid cancer. Cancer Sci. 2012;103(2): 305-309.

20. Mazzaferri EL, Kloos RT. Clinical review 128: current approaches to primary therapy for papillary and follicular thyroid cancer. J Clin Endocrinol Metab. 2001;86(4):1447-1463.

21. Podnos YD, Smith D, Wagman LD, Ellenhorn JD. The implication of lymph node metastasis on survival in patients with well-differentiated thyroid cancer. Am Surg. 2005;71(9):731-734.

22. DeGroot LJ, Kaplan EL, McCormick M, Straus FH. Natural history, treatment, and course of papillary thyroid carcinoma. J Clin Endocrinol Metab. 1990;71(2):414-424.

23. Mazzaferri EL, Young RL. Papillary thyroid carcinoma: a 10 year follow-up report of the impact of therapy in 576 patients. Am J Med. 1981;70(3): 511-518.

24. Howlader N, Noone AM, Krapcho M, et al. SEER Cancer Statistics Review, 1975-2009 (Vintage 2009 Populations). National Cancer Institute 2009 .
OncoTargets and Therapy

\section{Publish your work in this journal}

OncoTargets and Therapy is an international, peer-reviewed, open access journal focusing on the pathological basis of all cancers, potential targets for therapy and treatment protocols employed to improve the management of cancer patients. The journal also focuses on the impact of management programs and new therapeutic agents and protocols on

\section{Dovepress}

patient perspectives such as quality of life, adherence and satisfaction. The manuscript management system is completely online and includes a very quick and fair peer-review system, which is all easy to use. Visit http://www.dovepress.com/testimonials.php to read real quotes from published authors. 